\title{
AS PERSONAGENS AUTORREFLEXIVAS DE PIRANDELLO: SER OU PARECER?
}

\section{Pirandello's self-reflexive characters: to be or to look like?}

\author{
Andrea Quilian de Vargas* \\ Rosani Ketzer Umbach**
}

\begin{abstract}
RESUMO
Descendente do Verismo italiano, Luigi Pirandello se destacou no cenário da dramaturgia e da literatura italianas do final do século XIX e início do XX. No que se refere à representação, evidencia-se, em sua obra, uma importante diferença entre ele e seus predecessores: enquanto as personagens veristas pretendiam ser cópias do real, apontando para um determinado modelo humano do qual acreditavam ser as intérpretes, as criações pirandellianas denunciaram o mundo e o homem, apresentando-se como construtos submetidos exclusivamente à linguagem, e não como imitações de uma suposta realidade. A abordagem metodológica empregada neste trabalho é a análise de algumas obras de Pirandello, incluindo romances e peças teatrais, com o intuito de observarmos a trajetória transformativa de suas personagens e as características comuns que as aproximam. Foi possível constatarmos, dessa forma, o surgimento de seres ficcionais metateatrais, autorreflexivos, que não aceitam ter outro rosto que não o da ficção, configurando-se, dessa forma, na própria antítese ao Naturalismo.
\end{abstract}

Palavras-chave: Pirandello,representação, personagem

\begin{abstract}
Luigi Pirandello is a descendant of the Italian Verism. He became known in Italian dramaturgy and literature in the end of the XIX century and beginning of the XX. Regarding repre-

* Universidade Federal de Santa Maria (UFSM).

** Universidade Federal de Santa Maria (UFSM).
\end{abstract}


sentation, his work highlights an important difference between him and his predecessors: at the same time Verist characters intended to be copies of reality, froma determined human model, whose they believed to be interpreters, the creations of Pirandello denounced both the man and the world. Instead of being mere imitations of a supposed reality, his characters present themselves as the result of a building process, submitted exclusively to language. The methodological approach applied in this paper is the literary analysis of some novels and plays by Pirandello, with the purpose of observing the changing path of his characters as well as the common characteristics that bring them close to each other. It was possible to find the emergence of metatheatrical self-reflexive fictional beings, which are characters that do not accept another face but the fictional one. Such denial characterizes the very antithesis to Naturalism.

Keywords: Pirandello,representation, character.

"Ora, senhores, sou aquele por quem me tomam."

(Pirandello)

Movimento literário italiano iniciado na segunda metade do século XIX, mais especificamente nos últimos 30 anos, o Verismo traz à tona a intenção dos escritores de aderir mais significativamente à realidade social da época, através de uma narrativa que primava pela rigorosa fidelidade ao real, à verdade dos fatos e aos ambientes, características que aproximavam o Verismo do Naturalismo francês. Mas as aproximações não eliminam as distinções. Enquanto o segundo era desenvolvido em uma sociedade industrializada e em um contexto predominantemente urbano, o primeiro limitava-se ao âmbito rural, atrasado sob o ponto de vista econômico e cultural. Além disso, ao passo que os naturalistas franceses propagavam uma certa crença no progresso, a ideologia presente nos textos veristas mostrava-se fortemente pessimista. A melhoria das condições de vida das classes mais baixas parecia impossível: nas narrativas, os esforços para melhorar a situação das personagens, predominantemente campesinos, pequenos agricultores ou pescadores, quase sempre culminavam em tragédia.

Os sicilianos Giovanni Verga e Luigi Capuana, juntamente com o napolitano Federico De Roberto, são os maiores expoentes do Verismo. o fundador do movimento é, reconhecidamente, verga, com os romances I Malavoglia (1881) e Mastro-don Gesualdo (1889), a coletânea de contos Vita dei campi (1880) e a novela Novelle rusticane (1883), obras que apresentavam, em termos de linguagem, uma importante novidade. Uma vez que os 
protagonistas eram quase todos analfabetos e incultos, o escritor empregava um vocabulário diferenciado, incorporando o uso de expressões idiomáticas do local, típicas da oralidade, com forte influência dialetal.

O verdadeiro teórico do Verismo italiano foi Luigi Capuana, professor na Universidade de Catania, função que talvez tenha elevado a um nível de reflexão mais crítica as obras do período verista. Em seus romances Giacinta (1879) e Il marchese di Roccaverdina (1902), os temas mais rústicos de Verga se alternavam ao interesse pela atormentada psicologia das personagens, muitas vezes chegando ao limite da morbidez. A realidade siciliana, em especial, era o principal objeto de representação dos romances veristas; no entanto, a vertente literária não se esgotou nos limites da Sicília, espraiando-se por toda a Itália.

É a partir desse contexto artístico que tem início a obra do siciliano Luigi Pirandello (1867-1936), o qual ora se aproxima, ora se afasta dos moldes veristas. A aproximação decorre de seu interesse em explorar aspectos psicológicos nas personagens; o afastamento advém da insatisfação de Pirandello ao ler seus primeiros contos e não ver neles representado o homem moderno, fraturado e incompleto. Visualizava, ao contrário, a multiplicação e a repetição de enredos, situações, personagens, ambientes e estados de espírito, em textos contaminados pela referencialidade verista ao narrar. Uma personalidade como a de Pirandello, contrária à composição dos personagens "tipo" (nos moldes de Lukács), delimitados por todos os lados, compactos, acabados, haveria de encontrar uma maneira de transgredir o Verismo. Segundo João Carlos Felix de Lima (2012, p.106),

Quando estudante universitário, em Bonn, Pirandello já vinha elaborando experimentos de uma prosa mais límpida, mais avessa à retórica tradicional antirettórica. Difícil dizer o que o acompanhava nesta época, mas pode-se esboçar que as imagens expostas indicavam uma medida de homem contemplado, de homem existencialmente vívido, e sua recusa à representação desse homem nos moldes veristas [...] seria menos encontrável nos contos.

Para se desvencilhar da referencialidade da narrativa verista, Pirandello passa, então, a privilegiar a observação do homem dissociado de uma perspectiva totalizante, como produto de alguma espécie de clivagem econômica, nacional, representativa, comum nos romances realistas, mas, de forma contrária, como sujeito individualizado. Paradoxalmente, o caráter universal das criações de Pirandello resulta mais de sua aguda atomização do que de generalidades. Em algumas dessas personagens, é perceptível a luta pela expressividade que escapa aos apelos de uma história advinda de determinado fluxo cultural e econômico mais evidente. Em outros termos, 
pode-se afirmar que a natureza e a sociedade não determinam quem essas personagens são.

Dentre as mais perturbadoras indagações que perpassam toda a poética pirandelliana, repleta de contrastes, está: é possível saber quem somos? o que é verdadeiro e o que é falso? Quem vê com maior clareza: o sábio ou o louco? Somos pessoas ou personagens? O riso ou o pranto? A fé ou o mito? Representamos, para Luigi Pirandello, eternos pontos de interrogação. O que dizer, então, das personagens romanescas ou teatrais que se queriam espelho de uma sociedade que há tempo teatraliza seus papéis? No prefácio de 40 novelas de Luigi Pirandello, Maurício Santana Dias afirma que a questão central de Pirandello é:

como representar uma experiência subjetiva - do autor, do leitor, de qualquer um - em um mundo que parece esvaziar-se aceleradamente de sua concretude objetiva? Ou, em outros termos, como fazer a literatura expressar a relação entre esse sujeito, cada vez mais isolado e transformado em mônada, e aquilo que supostamente seria exterior a ele, mas que já não lhe garante nenhuma certeza? (PIRANDELLO, 2008, p. 8).

Ainda de acordo com Dias, Pirandello foi um dos primeiros escritores italianos a perceber e elaborar sistematicamente em sua obra a mutação antropológica que se processava no início do século XX. O reflexo de tal percepção fora a transição do Realismo, ou Verismo italiano, para uma literatura psicológica, passando por todas as formas tradicionais: o romance, a narrativa curta, o teatro e a poesia, num processo contínuo de erosão desses modelos que culminou em Um, nenhum e cem mil, que pode ser considerado um anti-romance (entendido como narrativa vanguardista que rompe com a norma, as tradições e escolas estabelecidas), e Seis personagens à procura de um autor, sua mais conhecida e também mais subversiva peça metateatral. Em 40 novelas de Luigi Pirandello, o professor e tradutor Maurício Santana Dias cita o crítico italiano Giancarlo Mazzacurati, para quem as personagens fraturadas de Pirandello são

Heróis da vida intersticial, sobreviventes de uma catástrofe da ideologia oitocentista cujo estrondo só se ouvirá plenamente durante a Grande Guerra. Eles já pedem para viver não acima nem dentro, mas debaixo da história; e, enquanto os Andrea Sperelli ou os Giorgio Aurispa [personagens de Gabriele d'Annunzio] reclamavam uma identidade mais forte do que o tempo que estavam atravessando [...], estes, ao contrário, buscarão uma ética mais fraca ou flexível, em matizes intemporais ou nas dobras secretas de uma sociedade já massificada (MAZZACURATI, 1998, p. 117118,in PIRANDELLO, 2008, p. 9). 
A galeria de anti-heróis pirandellianos (Mattia Pascal, Vitangelo Moscarda, Senhor Ponza, por exemplo) comprova a condição de sobreviventes referida por Mazzacurati, sendo importante destacar que as personagens sobrevivem ao contexto histórico, mas principalmente sobrevivem ao próprio autor, agora esmaecido pela autonomia da criatura em relação ao criador.

De acordo com Martha de Mello Ribeiro, em um ensaio intitulado $O$ jogo da personagem pirandelliana frente à realidade, apresentado no II Enletrarte, em 2004, para dar conta da problemática de uma suposta realidade,

Pirandello adapta a mimesis aos novos tempos, oferecendo à conturbada sociedade moderna um novo modelo de personagem. $O$ projeto teatral proposto por Pirandello não rompe definitivamente com a ideia de mimesis, mas inverte suas bases, ou seja, a realidade do palco se torna mais real que a realidade da vida objetiva. Sobre a realidade em que vivemos, afirma Pirandello, se arrastam bonecos de cera, cópias da máquina social, e a arte, enquanto cópia objetiva desta realidade, não poderá produzir nada mais que fantoches. A personagem fantoche seria, para Pirandello, uma cópia rasa das ações humanas julgadas verossímeis (RIBEIRO, 2004).

Ribeiro continua afirmando que a personagem dramática não é uma cópia objetiva do real, como julgava a estética naturalista, mas o produto de um ato epistemológico na medida em que não retrata a realidade do universo, mas as realidades que somos capazes de perceber. Como diz Pirandello: Assim $e ́$ (se lhe parece). Ao observarmos a trajetória transformativa das criações pirandellianas, é possível constatarmos o surgimento de uma personagem metateatral, autorreflexiva, que não aceita ter outro rosto que não o da ficção, configurando-se, dessa forma, na própria antítese ao Naturalismo. Os indivíduos autorreflexivos de Pirandello, em vez de viver, desejam ver-se vivendo, interrogam a própria vida, subvertem a existência, enfrentam a tortura que significa desfazer-se das máscaras sob as quais o ser e até mesmo a personagem se escondem. Para tanto, as criaturas tentam se desvencilhar de suas histórias originais e migrar para outros enredos, numa tentativa de libertação. Entretanto, é dessa forma que se configura o paradoxo da personagem: distanciada do papel a ela concedido pelo autor, ao tentar viver uma experiência independente do roteiro, a personagem deixa de possuir uma existência válida e cai no terrível anonimato, como podemos comprovar em Seis personagens à procura de um autor, peça em que os seres fictícios anseiam desesperadamente representar seus papeis. Conforme Ribeiro,

Ao se dar conta da necessária representação, da necessária escolha por uma máscara social, a personagem retorna à vida (à representação) e teatralizando-se, representando um papel, ela se fixa em uma forma e sacrifica a própria liberdade (RIBEIRO, 2004). 
Pirandello sabe, como aponta Mauricio Santana Dias no prefácio de 40 novelas de Luigi Pirandello (2008), que a vida como ela é, resta irrepresentável. Mas é preciso representá-la de algum modo, mesmo que a arte já não dê conta de nenhuma totalidade. Alinhada a esse pensamento, há uma importante diferença nas criações de Pirandello: enquanto as personagens "fantoche" 1 pretendem ser cópias do real, apontando para um determinado modelo humano do qual acreditam ser as intérpretes, as personagens pirandellianas denunciam o mundo e o homem como formas submetidas exclusivamente a uma linguagem, como aponta Ribeiro (2004), reivindicando seu papel enquanto personagens, e não como imitação de uma suposta realidade impossível de ser representada. Desfilam, na poética de Pirandello, seres fictícios que rompem com a normalidade, considerados aparentemente inverossímeis do ponto de vista realista ou naturalista, que assumem a ficção como verdade, tornando-a mais real do que a ficção do mundo, a qual todos somos submetidos compulsoriamente.

A ruptura com a representação é demarcada pela recusa à intriga tradicional e à personagem imitativa do real, comumente atrelada a referentes exteriores ao texto que, sob a perspectiva de Pirandello, deixa de ser um espelho do mundo para refletir somente a si mesmo. $O$ texto se torna a instância única dos desdobramentos de seus elementos, funcionando em uma rota contrária a dos grandes realistas modernos.

Em Mimesis, Erich Auerbach propôs-se a investigar a questão da representação da realidade e do foco narrativo em obras emblemáticas da literatura ocidental, partindo de textos antigos da cultura greco-latina, até contemplar autores da modernidade, como Stendhal, Balzac e Flaubert, sendo os dois primeiros considerados os fundadores do Realismo moderno, cujas bases estavam na aproximação da obra literária à realidade de cada contexto histórico específico. Nesse sentido, o ambiente exercia um poder impactante sobre o escritor e sua obra, como podemos verificar na reprodução das engrenagens sociais de Stendhal; nas aproximações entre pessoa e meio de Balzac; no realismo impessoal e objetivo de Flaubert. Os fundamentos do Realismo moderno, segundo Auerbach, estão no "tratamento sério da realidade quotidiana, na ascensão de camadas humanas mais largas e socialmente inferiores à posição de objetos de representação" (AUERBACH,

1 Termo empregado por Pirandello para designar as personagens meramente imitativas e subjugadas por seus autores. Seis personagens à procura de um autor, em especial, fornece essas informações ao leitor. Vejamos este exemplo: ao reclamar por ter de usar um gorro de cozinheiro, o primeiro ator é assim repreendido pelo diretor: "O gorro de cozinheiro, sim senhor! E bata os ovos! [...] Tem que representar a casca dos ovos que bate! [...] Sim, senhor, a casca; ou, em outras palavras: a forma vazia da razão, sem o recheio do instinto, que é cego. O senhor é a razão e sua mulher, o instinto, num jogo de papéis preestabelecido, no qual o senhor, que representa seu papel, é, involuntariamente, o fantoche de si mesmo. Compreendeu?" (PIRANDELLO, 1981, p. 356) 
1971, p. 440). Todos esses fatores são agudamente transgredidos por Luigi Pirandello, para quem a realidade quotidiana é uma farsa, assim como o ser humano, seja ele de classe inferior ou superior, é um fantoche manipulado justamente pelo meio representado nas obras realistas.

Ao condenar a representação do mundo real à falência, Pirandello confere às personagens descomprometidas com a realidade a possibilidade de intervirem diretamente no processo de criação. Em outros termos, a personagem determina seu próprio drama, contrariando o Realismo e o Naturalismo, os quais realizam sobre a cena, no caso do teatro, e sobre a narrativa, no caso da literatura, um meticuloso estudo histórico e social, sendo as personagens determinadas pelas necessidades do enredo. Em Luigi Pirandello, a peça ou o romance passa a ser o único universo dessas personagens, independentemente da suposta realidade do mundo. Estas, adquirindo autonomia, podem migrar de um texto para outro, de um tempo para outro, de um espaço a outro.

Tomemos como exemplo a peça Seis personagens à procura de um autor: durante o ensaio de uma companhia teatral, surgem seis personagens que reivindicam a presença de um autor que lhes dê a oportunidade de representarem o seu drama. Por intermédio de um diálogo insano entre personagens, atores e o diretor, Pirandello desnuda o processo criativo diante do espectador, põe em segundo plano os atores reais e confere vida própria às personagens. Por conta disso, choca tanto o público quanto a crítica. Logo no início da peça, estão no palco os atores, o diretor e o assistente, quando entram em cena seis personagens: o Pai, a Enteada, a Mãe, o Filho e mais um casal de crianças, os quais fazem rir a todos ao requisitarem um autor e se apresentarem como "personagens":

O DIRETOR: os senhores querem fazer graça?...

O PAI: Em absoluto! Que está dizendo, senhor? Ao contrário, trazemo-lhes um drama doloroso.

A ENTEADA: E podemos fazer a sua fortuna!

O DIRETOR: Façam-me o favor de ir embora! Não temos tempo a perder com loucos.

O PAI (ofendido, mas melífluo): Oh, senhor, sabe muito bem que a vida é cheia de infinitos absurdos, os quais, descaradamente, nem ao menos têm necessidade de parecer verossímeis. E sabe por que, senhor? Porque esses absurdos são verdadeiros. [...] Digo que, ao pensarmos nesses absurdos verdadeiros, que nem mesmo verossímeis nos parecem, vemos que a loucura consiste, justamente, no oposto: em criar verossimilhanças que pareçam verdadeiras. E essa loucura [...] é a única razão de ser da profissão dos senhores. O DIRETOR: [...] Acha que a nossa é uma profissão de loucos?... O PAI: Hum! Fazer com que pareça verdadeiro o que não o é, sem necessidade... só por prazer. O ofício dos senhores não consiste em dar vida, na cena, a personagens imaginárias? 
O DIRETOR: Pois eu lhe peço o favor de acreditar, meu caro senhor, que a profissão de ator é uma nobilíssima profissão! E, se hoje em dia os senhores teatrólogos modernos só nos dão peças cretinas para representar, e fantoches em vez de homens, saiba que nos gloriamos de ter dado vida, aqui, sobre essas tábuas, a obras imortais! O PAI: É isso mesmo![...] Dar vida a seres vivos, mais vivos que aqueles que respiram e vestem roupas! Menos reais, talvez, porém mais verdadeiros. Somos da mesma opinião.

$[\ldots]$

O DIRETOR: E o senhor, com essas outras pessoas em volta, nasceu personagem?

O PAI: Exatamente. E vivos, como nos vê.

( $O$ diretor os atores desatam a rir, como se tratasse de uma brincadeira.) (PIRANDELLO, 1981, p. 361-364).

Nas palavras do Pai encontra-se a síntese do que as personagens representam na obra de Pirandello: sua realidade pode ser menos real, mas é certamente mais verdadeira. Isso ocorre pelo simples fato de que, de acordo com o siciliano, não há, no mundo, uma realidade exclusiva ou definitiva, mas múltiplas possibilidades e perspectivas. A realidade, dessa forma, entra em colapso, juntamente com a noção de verdade, como afirma Raymond Williams em Tragédia moderna:

Podemos construir, para nós mesmos, uma ilusão e podemos temporariamente entrelaçá-la à ilusão de outra pessoa. Mas, enquanto a vida continua, o entrelaçamento é ameaçado, e tanto a pressão do outro, representando a sua própria ilusão, quanto ainda a sua distância, a impossibilidade de alcançá-lo verdadeiramente, são vivenciadas de modo trágico (WILLIAMS, 2002, p.197).

Nesse sentido, a personagem que se distancia do humano e se reconhece unicamente como personagem coloca-se acima do homem que, desprovido de uma identidade coesa e de uma realidade, busca, incessantemente, representar papeis, vestir máscaras, com a ingênua esperança de que pareçam reais. Em outras palavras, a personagem é dotada de uma verdade que o homem não possui.

Doutor Fileno, o ambicioso protagonista da novela $A$ tragédia de um personagem (1911), adverte o escritor a quem se dirige pedindo que este lhe escreva outra história, diferente da primeira, criada por outro autor. Tal autor, segundo Fileno, não o havia valorizado suficientemente:

Quem nasce personagem, quem tem a ventura de nascer personagem vivo, pode até mesmo esnobar a morte. Não morre mais! Morrerá o homem, o escritor, instrumento natural da criação; a criatura não morre mais! E, para viver eternamente, não necessita 
de dons extraordinários ou de feitos prodigiosos. Diga-me quem era Sancho Pança! Diga-me quem era D. Abbondio! Entretanto eles vivem para sempre porque, germes vivos, tiveram a sorte de encontrar uma matriz fecunda, uma fantasia que os soube criar e nutrir para a eternidade (PIRANDELLO, 2008, p. 357).

Na referida novela, há um embate entre criatura e criador. Doutor Fileno se revolta contra o escritor que o criara pelo fato de este não ter reconhecido, nele, matéria para uma grande história, uma grande obra capaz de imortalizá-lo. Dessa forma, Pirandello desconstrói a imagem soberana do autor, figura até então reconhecida como o centro criativo da produção literária. Fileno havia inventado algo inusitado, uma espécie de telescópio ao contrário, através do qual era possível afastar as coisas e as pessoas para vê-las com maior clareza. Sua invenção fora batizada como a "Filosofia da distância" (Pirandello, 2008, p. 356). Segundo o Doutor Fileno, vê melhor aquele que se distancia da coisa vista. $O$ narrador da novela $A$ tragédia de um personagem, um escritor, havia tomado conhecimento da existência de Fileno ao ganhar o livro no qual ele era uma personagem secundária. Sobre o desperdício dessa personagem tão rica, assim reflete o escritor narrador:

Durante a leitura do romance, pareceu-me óbvio que o autor, todo concentrado em amarrar artificiosamente uma trama das mais banais, não soubera assumir toda consciência desse personagem, o qual, contendo em si, isoladamente, o germe de uma criação autêntica, conseguira a certa altura tomar o autor pela mão e destacar-se por um longo trecho, com vigoroso relevo, dos comuníssimos casos ali narrados e representados; depois, de repente, perdida a forma e a altura, deixa-se dobrar e adaptar às exigências de uma solução falsa e simplória. [...] Que pena! Nele havia material suficiente para criar uma obra-prima! [...] E grande pena e despeito se apoderaram de mim, por aquela vida desgraçadamente malograda (PIRANDELLO, 2008, p. 356).

Essa personagem que tenta escapar do próprio texto, que clama por uma existência mais digna e ajustada às suas possibilidades e potencialidades, adquire tal plenitude que realoca para um segundo plano o fato de tratar-se de uma criatura ficcional. Aliás, realidade e ficção, em Luigi Pirandello, estão separadas por uma linha bastante tênue, que ora as aproxima, ora as afasta. Advertência sobre os escrúpulos da fantasia, um ensaio publicado pela primeira vez em 22 de junho de 1921, no jornal romano L'Idea nazionale, e incluído nas edições posteriores de O falecido Mattia Pascal, fora escrito por Pirandello em resposta às acusações de inverossimilhança proferidas pela plateia e os críticos que compareceram ao teatro na estreia da peça. Nesse texto, o dramaturgo siciliano realiza uma interessante aná- 
lise daquilo que pode ser considerado verossímil, na vida e na arte. Dois exemplos esclarecem satisfatoriamente o ponto. Conta-nos Pirandello que

Posto na encruzilhada entre o amor da esposa e o de uma moça solteira de 20 anos, o senhor Alberto Heintz, de Buffalo, nos Estados Unidos, acha de bom aviso convidar uma e outra para um encontro, a fim de tomarem, juntamente com ele, uma decisão. As duas mulheres e o senhor Heintz apresentam-se [...] no lugar aprazado; discutem longamente e, no fim, chegam a um acordo (PIRANDELLO, 1972, p. 313).

Ficou acordado que, naquele mesmo dia, cada um dos três deveria se suicidar. A senhora Heintz volta para casa, desfecha contra si um tiro de revólver, e morre. O senhor Heintz e sua jovem amante, então livres do empecilho que representava a senhora Heintz, resolvem ficar juntos. Infelizmente, a autoridade judiciária manda prendê-los. Essa matéria foi lida nos jornais de Nova York de 25 de janeiro de 1921.

O Corriere della Sera, conhecido jornal de Milão, aos 27 dias do mês de março de 1920, publicava a seguinte matéria: "A HOMENAGEM DE UM VIVO A SEU PRÓPRIO TÚMULO" (PIRANDELLO, 1972, p. 287). A notícia referia ao suposto suicídio do senhor Ambrogio Casati, eletricista, cujo corpo fora retirado de um canal e reconhecido pela esposa e por aquele que, mais tarde, viria a ser seu próximo marido. Entretanto, o cadáver encontrado não era do senhor Casati, pois esse estava preso por um crime contra a propriedade e vivia, de longa data, separado da mulher. Após sete meses de luto, a senhora Casati casa novamente com Maioli, sem encontrar qualquer dificuldade. Seu primeiro marido estava morto. Ao término da pena, senhor Casati retorna e, para sua surpresa e de todos, descobre que estava civilmente morto. Pirandello, após relatar o fato em Advertência sobre os escrúpulos da fantasia, assim escreve:

Não posso supor que o senhor Ambrogio Casati, eletricista, lesse o meu romance e levasse as flores à sua sepultura por imitação do falecido Mattia Pascal. A vida, entrementes, com seu imperturbável desprezo de toda verossimilhança, pode achar um padre e um prefeito que uniram em casamento o senhor Maioli e a senhora Tedeschi, sem preocupar-se de conhecer um elemento de fato, do qual talvez fosse facílimo ter notícia, ou seja, que o marido, senhor Casati, estava na prisão e não debaixo da terra (PIRANDELLO, 1972, p. 288-289).

Pirandello, profundamente contrariado com a estúpida obrigatoriedade da obra de arte em parecer verossímil, sustenta a seguinte ideia: 
As absurdidades da vida não precisam parecer verossímeis, porque são verdadeiras; ao contrário daquelas da arte, que, para parecerem verdadeiras, precisam ser verossímeis. E, então, verossímeis, não são mais absurdidades. Um caso da vida pode ser absurdo; uma obra de arte, se é obra de arte, não. Decorre, daí, que tachar uma obra de arte de absurdidade e inverossimilhança, em nome da vida, é um disparate. Em nome da arte, sim; em nome da vida, não (PIRANDELLO, 1972, p. 282).

Questionamo-nos, então, alinhados ao pensamento de Luigi Pirandello: será que somente a vida está autorizada a ser inverossímil? Sabemos que a literatura cria seu próprio universo semanticamente autônomo, cria sua objetividade própria, mesmo que essa realidade criada não deixe de ter relação com a realidade da vida objetiva. É a atitude seletiva do escritor em face da realidade do texto que irá criar um real possível internamente (a verossimilhança interna), com base na subjetividade criadora da mimeses proposta por Aristóteles. Nada disso impede que a vida copie esse universo, como pudemos constatar nos relatos de Pirandello. Isto posto, surge outra questão interessante: o que imita o quê? A arte imita o mundo, ou seria o contrário?

Em $O$ demônio da teoria, mais especificamente no capítulo $O$ mundo, Compagnon parte do princípio de que "ler com vistas à realidade [...] é enganar-se sobre a literatura" (COMPAGNON, 2001, p. 97). Para fortalecer seu argumento, o crítico cita Philippe Sollers que, em 1965, denunciava o pretensioso Realismo "que consiste em acreditar que uma escritura deve exprimir alguma coisa que não é dada nesta escritura, alguma coisa sobre a qual a unanimidade pode se fazer imediatamente" (COMPAGNON, 2001, p. 97). A impossibilidade de consonância interpretativa subjaz ao fato de ser a própria realidade uma convenção, um acordo entre indivíduos e seus respectivos grupos, sendo, portanto, relativa. Ainda na parte inicial de $O$ mundo, ao tratar do tema da referencialidade na literatura e buscando suporte na linguística, Compagnon cita Ferdinand de Saussure, para quem o exterior referencial da linguagem não importa:

Em Saussure, a ideia do arbitrário do signo implica a autonomia relativa da língua em relação à realidade e supõe que a significação seja diferencial (resultado da diferenciação entre os signos) e não referencial (relação entre as palavras e as coisas) (COMPAGNON, 2001, p. 99).

O russo Roman Jakobson, um dos maiores linguistas do século $\mathrm{XX}$, compartilha de semelhante posicionamento. Para ele, na "arte da linguagem", a literatura, a função poética prevalece consideravelmente 
em relação às funções referenciais e denotativas. Já para Roland Barthes, também citado por Compagnon,

A função da narrativa não é a de "representar", mas de constituir um espetáculo que ainda permanece muito enigmático, mas que não poderia ser de ordem mimética. [...] "O que se passa" na narrativa não é, do ponto de vista referencial (real), ao pé da letra, nada; "o que acontece", é só a linguagem inteiramente só, a aventura da linguagem, cuja vinda não deixa nunca de ser festejada (COMPAGNON, 2001, p. 101).

Todavia, as colocações de Barthes parecem um tanto radicais, especialmente ao afirmar que aquilo que se passa na narrativa não é "nada" além da própria linguagem. Segundo Compagnon, para que a "aventura" da linguagem exista, ela necessita referir-se a alguma coisa que existe no mundo real. Nesse sentido, torna-se impossível dissociar literatura e mundo, pois

Na ficção se realizam os mesmos atos de linguagem que no mundo real: perguntas e promessas são feitas, ordens são dadas. Mas são atos fictícios, concebidos e combinados pelo autor para compor um único ato de linguagem real: o poema. A literatura explora as propriedades referenciais da linguagem; seus atos de linguagem são fictícios, mas, uma vez que entramos na literatura, que nos instalamos nela, o funcionamento dos atos de linguagem fictícios é exatamente o mesmo que o dos atos de linguagem reais, fora da literatura (COMPAGNON, 1999, p. 135).

Assim, por mais que a composição ficcional não seja o mundo real, com ele estabelece constante comunicação. O mundo ficcional é, então, um mundo em potência materializado através da linguagem. O livro é, sem dúvida, um mundo. Mas o mundo também é um livro, repleto de infinitas possibilidades, que nem sempre segue ordens ou funciona de acordo com as leis do universo. Como esperar, então, que a literatura represente um utópico mundo perfeito? É justamente a imperfeição do mundo e do ser humano que interessam a Luigi Pirandello, o qual carrega as tintas na força da personagem defeituosa, feia, problemática como um ser repleto de realidade.

No início do século XX, assistimos a uma considerável transformação da personagem romanesca e teatral, a chamada "crise da personagem". Para entendermos o significado dessa expressão, é interessante partirmos das considerações de um grande crítico literário italiano chamado Giacomo Debenedetti, o qual escreve: 
Appena ci si mette a leggere i romanzi moderni si è colpiti da un fatto abbastanza sconcertante. Dal ritratto dei personaggi scompare, quasi senzaeccezione, ogni vestigio di bellezza fisica, specialmente nella faccia, cioè nella parte più espressiva della persona. [...] In breve, col finire della narrativa naturalista [...] comincia nel romanzo e nel racconto l'invasione vittoriosa deibrutti, che a non lungo andare occuperanno tutto il territorio. [...] Per rimanere nell'ambito italiano, si guardino i personaggi di Pirandello e di Federigo Tozzi, i due veri iniziatori del romanzo moderno in Italia. A mettere insieme ivisi e le figure di quella gente, si ricava poco meno che un'adunata da moderna Corte dei Miracoli: un repertorio di rappresentanti dello squallido, dello scostante, dello scontroso, dell'inameno, dello scombinato, del repulsivo. [...] Pirandello ha dunque intuito [...] l'eziologia dell'affezione deformante che interessa prima di tutto i tratti facciali, imprime sul viso una facies 1 che lo dissesta e gli dà un'espressione disofferenza. [...] Comunque, l'agente patogeno è l'Altro, che fa sentire la sua presenza dentro l'Io, se vogliamo usare la terminologia di Rimbaud (DEBENEDETTI, 1988).

A consideração de Debenedetti parece, em um primeiro momento, limitar-se a um nível exclusivamente estético: a beleza física da personagem. Todavia, o conceito pode ser ampliado para um plano menos material, atingindo as esferas ética, estética e moral. É fato que, especialmente a partir dos anos 1900, já não é mais possível tratar a personagem se não como um ser fraturado e problemático, contrário ao equilibrado, sereno e belo sujeito da arte antiga. Em seu famoso ensaio L'umorismo (1908), traduzido para o português pelo professor Jacó Guinsburg, assim escreve Pirandello:

Vejo uma velha senhora, com os cabelos retintos, untados de não se sabe qual pomada horrível, e depois toda ela torpemente pintada e vestida de roupas juvenis. Ponho-me a rir. Advirto que aquela velha senhora é o contrário do que uma velha respeitável senhora deveria ser. Assim posso, à primeira vista e superficialmente, deter-me nessa impressão cômica. O cômico é precisamente um advertimento do contrário (PIRANDELLO, 1999, p. 147).

Inicialmente o cômico, na cena, advém do fato de que a descrição não corresponde ao que esperamos visualizar em uma senhora. Ao contrário, a imagem é feia e ridícula, ocasionando um choque entre a maneira como ela efetivamente é e como se esperava que ela fosse. Contudo, analisando mais calmamente e refletindo sobre o aspecto risível da figura, Pirandello nos faz perceber a tênue distinção entre o cômico, oriundo de uma superficial e vazia observação de algo que contraria o esperado, e o humorístico: 
Mas se agora em mim intervém a reflexão e me sugere que aquela velha senhora não sente talvez nenhum prazer em vestir-se como um papagaio, mas que talvez sofra por isso e o faz somente porque se engana piamente e pensa que, assim vestida, escondendo assim as rugas e as cãs, consegue reter o amor do marido, muito mais moço do que ela, eis que já não posso mais rir disso como antes, porque precisamente a reflexão, trabalhando dentro de mim, me leva a ultrapassar aquela primeira advertência, ou antes, a entrar mais em seu interior: daquele primeiro advertimento do contrário ela me faz passar a esse sentimento do contrário. E aqui está toda a diferença entre o cômico e o humorístico (PIRANDELLO, 1999, p. 147).

Quando algo ou alguém contrasta com as expectativas ou difere do senso e da estética comuns, o efeito provocado é, na maioria das vezes, o riso cômico, como aponta Pirandello. Todavia, a essa primeira advertência de que algo contraria a normalidade pode surgir uma reflexão bem mais profunda, um "sentimento do contrário". Aí está a diferença entre o cômico e o humorístico. O primeiro representa a fase inicial e superficial do verdadeiro conhecimento, enquanto o segundo é o sentimento que nasce da percepção de que a realidade é justamente o contrário daquilo que está visível. Segundo Pirandello,

o artista comum cuida somente do corpo: o humorista cuida do corpo e da sombra, e talvez mais da sombra que do corpo; nota todos os gracejos desta sombra, como ela ora se alonga ora se encolhe, quase a fazer o arremedo do corpo, que no entanto não a calcula e nem se preocupa com ela (PIRANDELLO, 1999, p. 177).

Pirandello, intentando uma reflexão crítica, coloca em primeiro plano aquilo que aparece, o visivelmente ridículo, para revelar a realidade por detrás daquilo que realmente é, atribuindo ao riso um caráter subversivo e, até mesmo, anárquico, fato que ratifica sua posição sempre contrária à possibilidade de representação da realidade. Há, para o siciliano, uma larga distância entre aquilo que vemos e aquilo que realmente é. o humorista, nessa linha, é o artífice da farsa trágica da vida, e o humorismo, sob essa perspectiva, está intimamente relacionado à atitude subversiva de Pirandello, o qual relaciona o humorismo à distinção entre a arte antiga e a arte moderna. Esta é caracterizada pela "exaltação dos sentimentos, o vago, o infinito, o indeterminado das aspirações, as melancolias, a nostalgia, a beleza interior [...]" (PIRANDELLO, 1999, p. 52); aquela, reconhecida pela "serenidade marmórea, o equilíbrio digno, a beleza exterior" (PIRANDELLO, 1999, p. 52). Percebe-se, então, que estes dois vetores antitéticos, a arte clássica e a arte moderna, se contrapõem no que Pirandello denomina hu- 
morismo, cujo objetivo é a desconstrução histórica do ideal. A incoerência da arte moderna opõe-se à harmonia da arte antiga; as particularidades singulares contrapõem-se às tipificações clássicas; o real desafia o ideal; o feio sobrepõe-se ao belo; o genérico rivaliza com o diferenciado.

Sobre a inclinação humana às generalizações, Pirandello adverte que

Tal como na formação de uma lenda, a imaginação coletiva rejeita todos os elementos, os traços, os caracteres discordantes da natureza ideal de um fato dado ou de uma dada personagem e evoca, ao invés, e combina todas as imagens convenientes; assim, ao traçar brevemente a síntese de uma dada época, inevitavelmente somos induzidos a não ter em conta tantos detalhes em contradição, de expressões singulares. Não podemos prestar ouvidos às vozes que protestam em meio a um coro sobrepujante (PIRANDELLO, 1999, p. 54).

Prosseguindo, Pirandello alerta para a necessidade de o artista moderno dirigir o olhar para a singularidade do indivíduo, para aquilo que o homem não quer ver, para a feiura, para a anomalia, para o grotesco.

Na verdadeira realidade, as ações que põem em relevo um caráter se recortam sobre um fundo de vicissitudes ordinárias, de particularidades comuns. Pois bem, os escritores, em geral, não se valem disto, ou pouco se importam, como se estas vicissitudes, estas particularidades não tivessem valor nenhum e fossem inúteis e omissíveis. O humorista, ao invés, as entesoura. [...] E o imprevisto que há na vida? E o abismo que há na alma? [...] Daí que, no humorismo, se encontre toda aquela busca das particularidades mais íntimas e minuciosas, que podem inclusive parecer vulgares e triviais se forem confrontadas com as sínteses idealizadoras da arte em geral, e aquela busca dos contrastes e das contradiçóes, [...] todas aquelas digressões que se notam na obra humorística, em oposição à estrutura ordenada, à composição da obra de arte em geral (PIRANDELLO, 1999, p. 176-177).

O que há em Pirandello é uma postura que desestabiliza, contrariando a arte em geral que, no final do século XIX e primórdios do XX, abstrai e concentra, capta e representa a idealidade das coisas e dos indivíduos. Ao humorista, tudo isso parece simplificado demais, coerente demais.

A questão do humorismo, em Pirandello, também está ligada a duas das grandes interrogações que perpassam toda sua poética: a distinção entre a vida e a forma; entre a realidade e a ficção. Vida, entendida aqui como um conjunto de possibilidades existenciais; forma, como a escolha dentre essas possibilidades; realidade, como uma construção superficial; 
ficção como a única realidade confiável. Sob esse prisma, as personagens pirandellianas impossibilitam quaisquer tentativas de síntese por parte do leitor ou espectador a partir da caracterização ou do aspecto físico, tendo em vista que, apegados a uma suposta noção de real, podemos ser facilmente enganados e rir de quem carrega o peso de uma tragédia, ou compadecer-nos pelo sorriso de um vilão ardiloso. O humorista, segundo Pirandello, vê o rei em mangas de camisa, o mesmo rei que o artista comum enxerga coberto por seu majestoso manto vermelho. "O homem é um animal vestido - diz Carlyle em seu Sartor Resartus- a sociedade tem por base o vestuário.' E o vestuário [assevera Pirandello] compõe também, compõe e esconde: duas coisas que o humorismo não pode suportar" (PIRANDELLO, 1999 p. 176).

Ao tratar do humorismo, Pirandello quer estabelecer um campo de tensão cujo motor seja a reflexividade, a autoanálise do sujeito, bem ao modo de suas personagens autorreflexivas. O humorismo é um dos pontos-chave de sua poética, calcada nas inquietantes contradições entre ser e parecer, entre o que é verdadeiro e o que é falso, entre ficção e realidade.

Em Advertência sobre os escrúpulos da fantasia, Pirandello afirma que há, na história natural, um reino estudado pela zoologia, povoado de animais. Dentre esses animais, está o homem, que não é um quadrúpede, mas um bípede, que não tem cauda, como o macaco ou o burro. A esse homem, segundo Pirandello, não pode acontecer nenhuma desgraça, como perder uma perna ou um olho:

O homem do zoólogo tem sempre duas pernas, nenhuma delas de pau; tem sempre dois olhos, nenhum deles de vidro. E é impossível contradizer o zoólogo. Porque o zoólogo, se lhe apresentarmos um fulano com uma perna de pau ou com um olho de vidro, responderá que não o conhece, porque aquele não é o homem, mas um homem. É verdade, porém, que todos nós, por nossa vez, podemos responder ao zoólogo que o homem que ele conhece não existe e que [...] existem os homens, nenhum dos quais é igual ao outro, e que podem, inclusive, por uma desgraça, ter uma perna de pau ou um olho de vidro (PIRANDELLO, 1972, p. 283).

À fôrma do zoólogo, que enquadra, caracteriza, classifica e não admite aberrações ou nada que destoe do compasso orquestrado pelas mãos divinas ou pelas leis da biologia ou da física, Pirandello responde com as absurdidades de suas personagens e seus enredos, contrapondo realidade e ficção, realidade e expectativa. Assim escreve o siciliano em Um, nenhum e cem mil:

Porém me esforçarei para lhes dar, não duvidem, aquela realidade que vocês creem possuir, ou seja, tentarei criar em mim aquela realidade que vocês querem. Isso não é possível, como muito bem 
o sabemos, já que, fora os esforços que eu faça para representar-me a seu modo, será sempre "um modo seu" apenas para mim, não "um modo seu" para vocês e para os outros. Mas me desculpem: se para vocês eu não tenho outra realidade além daquela que vocês me dão, e estou pronto a reconhecer que ela não é menos verdadeira do que aquela que eu poderia me dar, que esta é, aliás, a única verdadeira a seus olhos (e Deus sabe qual é essa realidade que vocês me dão), talvez agora vocês se lamentem daquela que eu lhes darei, mesmo com toda a boa vontade de representá-los ao seu modo, na medida das minhas possibilidades. Não presumo que vocês sejam como eu os represento. Já afirmei que vocês não são nem sequer aquele um que se representam a si mesmos, mas muitos ao mesmo tempo, segundo todas as suas possibilidades de ser e os casos e as relações e as circunstâncias. E então, qual o meu erro? Vocês é que se equivocam em relação a mim, achando que eu não tenho ou não posso ter outra realidade afora esta que vocês me dão, a qual é apenas sua, acreditem; uma ideia sua, aquela que fizeram para mim, uma possibilidadede ser tal como vocês a percebem, como lhes parece, como reconhecem possível em vocês - já que, sobre aquilo que eu possa ser para mim, não só vocês não podem saber nada, mas tampouco eu mesmo (PIRANDELLO, 2010, p. 94).

O desmoronamento do ser humano e de todas as certezas a respeito de si mesmo é claro no fragmento. A partir dele, podemos depreender do que trata a obra de Pirandello: as dialéticas eu x outro; realidade x ficção. Esse diálogo, imanente à obra do dramaturgo, poderá nortear nossas reflexões acerca das possibilidades de representação na obra pirandelliana. Para que possamos fazer as relações pertinentes ao fragmento citado, voltemos ao início de Um, nenhum e cem mil, romance elaborado entre 1916 e 1926. Ao descobrir que tinha o nariz torto, Vitangelo Moscarda submerge em um penoso processo de desintegração pessoal e de decomposição das tantas imagens que os moradores da pequena cidade haviam construído dele. $\mathrm{Na}$ apresentação à edição de 2010, Alfredo Bosi tece as seguintes considerações:

O protagonista, Vitangelo Moscarda, jovem rico e ocioso, intui, a partir de certo momento, a verdade lancinante da coexistência social. Que o episódio dessa revelação contenha em si um fato ridículo (um comentário sarcástico da mulher de Moscarda sobre um defeito em seu nariz...), apenas põe a nu a fragilidade do nosso eu, em face do olhar do outro. Vitangelo aprende, em um relance, que somos para os outros tão-somente o que parecemos. Convém adequar-nos a essa aparência pública, e a todas as generalità que ela comporta. [...] Se para os outros existiam tantos e tantos Moscardas, cem mil aspectos e perfis de sua persona aparente, para 
ele próprio parecia não haver um único eu que pudesse subsistir e resistir fora da opinião alheia. Para si próprio ele, afinal, era ninguém (PIRANDELLO, 2010, p. 10).

Completamente imerso em um turbilhão de reflexões, Moscarda decide alterar os fatores e resistir ao determinismo, "escolhe escolher" em vez de viver à deriva das circunstâncias. Desfaz-se do dinheiro, da casa, do nome, da esposa (essa, aliás, já o havia abandonado), das roupas, e vai viver em um hospício, assumindo, assim, a condição de louco. Inicialmente, rimos ao visualizar Moscarda com o rosto escondido por detrás da espessa barba, vestindo seu camisolão azul, com seus chinelões de hospício, como ele mesmo se refere. Rimos, especialmente quando lembramos qual fora a motivação inicial da loucura de Moscarda: o nariz levemente torto . No entanto, o riso perde o sentido quando nos damos conta de que ele provém de uma tragédia, a tragédia da vida representada nas páginas do livro: quem somos? Um? Nenhum? Cem mil? De uma situação cômica, passamos a um estranho estado de tristeza relacionado à tomada de consciência da completa insipiência do homem em relação a ele mesmo. Em Pirandello, é sempre aconselhável duvidar do riso. Sobre sua comicidade, assim pontua Alfredo Bosi:

Mas o objetivo de Pirandello [...] é ir além da comicidade, e colher, por trás do mero ridículo, a secreta amargura, a mascarada frustração. Nesse refletir e exprimir o contraste entre o que parece e o que deve ser, reside a capacidade específica do humorista. Ele não se contenta com as fugazes impressões que provocam o riso: sua natural disposição de ânimo, seu humor predominante, para dizê-lo à antiga, levam-no a descobrir os motivos contraditórios de cada situação humana. Daí o conceito de Pirandello: o humor é o sentimento do contrário (BOSI, 1988, p. 188-189).

Em outras palavras, o verdadeiro humor pirandelliano está justamente onde é possível percebermos a agonia dos contrastes; é pensar o riso como decorrente de uma suposta anormalidade, ou uma tragédia, o que nos leva a uma tomada de consciência acerca da impossibilidade mimética em função da inexistência de uma visão absoluta ou generalizante do mundo. Pirandello se nega, portanto, a compactuar com os moldes tradicionais de representação. Ao contrário, opta pela subversão da arte mimética em nome da recusa à ilusão referencial tradicional, ao mesmo tempo em que retira do autor o poder absoluto sobre a personagem. o palco, para Pirandello, é um local de prova e investigação acerca da arte e do ser humano, cujas cortinas jamais estão fechadas, para que o processo todo se desvende aos olhos do espectador, deixando os segredos restritos à complexidade da figura huma- 
na, para ele irrepresentável. O núcleo vital da obra de Pirandello está no abandono total da representação "como se fosse" a vida ou "como se fosse" um homem do Realismo e do Naturalismo, optando pelo desequilíbrio, a dissonância e a fratura do sujeito que faz careta e duvida da própria realidade.

Fiç̧ão! Realidade! Vão para o diabo todos vocês!

Luzes!

(Pirandello)

\section{REFERÊNCIAS}

AUERBACH, Erich. Mimesis. Tradução de: Suzi Sperber. São Paulo: Perspectiva, 1971.

BOSI, Alfredo. Céu, inferno: ensaios de crítica literária. São Paulo: Editora Ática, 1988.

. Itinerariodella narrativa pirandelliana. Tese (Doutorado emLetras) - Universidade de São Paulo, São Paulo, 1964.

COMPAGNON, Antoine. O demônio da teoria: literatura e senso comum. Tradução de: Cleonice Paes Barreto Mourão; Consuelo Fortes Santiago. Belo Horizonte: Ed. UFMG, 2001.

DEBENEDETTI, Giacomo.Il personaggio uomo. Milano: Garzanti, 1988.

LIMA, J. C. Cultura, Imaginação Literária e Resistência em Afredo Bosi. 619 f. Tese (Doutorado em Letras) - Universidade de Brasilia, Brasilia, 2012.

MAZZACURATI, Giancarlo. Le stagioni dell'apocalisse: Verga, Pirandello, Svevo. Torino: Einaudi, 1998.

PIRANDELlo, Luigi. 40 novelas de Luigi Pirandello. Tradução de: Maurício Santana Dias. São Paulo: Companhia das Letras, 2008.

. Esta noite se representa de improviso. In: GUINSBURG, J. Pirandello: do teatro no teatro. Tradução de: J. Guinsburg. São Paulo: Perspectiva, 1999.

L'umorismo. Roma: Tascabili Economici Newton, 1993.

Editora Civilização Brasileira, 1972.

O falecido Mattia Pascal. Tradução de: Mário da Silva. Rio de Janeiro:

. O falecido Mattia Pascal; Seis personagens à procura de um autor. Tradução de: Mário da Silva; Brutus Pedreira; Elvira Rina. São Paulo: Abril Cultural, 1981.

Cosac Naify, 2010.

. Um, nenhum e cem mil. Tradução de: Maurício Santana Dias. São Paulo:

RIBEIRO, Martha. O confronto entre ator e personagem em Pirandello.Graphos, João Pessoa, v. 12 , n. 1, p. 103-117, jun. 2010.

O jogo da personagem pirandelliana frente à "realidade". In:ENCONTRO

NACIONAL DE PROFESSORES DE LETRAS E ARTES (ENLETRARTE): Signos em rotação - a literatura e outros sistemas de significação, 2., 2004. Campos. Anais... Campos: CEFET, 2004. v. 2.

WILLIAMS, Raymond. Tragédia moderna. Tradução de: Betina Bichof. São Paulo: Cosac Naify, 2002.

Submetido em: 13/02/2015

Aceito em: 06/03/2015

Revista Letras, Curitiba, N. 91 p. 89-107, JAN./JUN. 2015.

ISSN 2236-0999 (VERSÃo ELETRÔNICA) 